\title{
DEMONY PRZYBYSZEWSKIEGO, CZYLI O SZATANIE WCZESNEJ NOWOCZESNOŚCI
}

Gabriela Matuszek

\section{/// 1. Pusta transcendencja}

Jednym z centralnych zdarzeń wczesnej nowoczesności była „śmierć Boga" i wynikające $z$ tego faktu nihilistyczne konsekwencje (Por. Sheppard 1998). Antropoteizm Ludwiga Feuerbacha, anarchizm metafizyczny Maxa Stirnera, pozytywistyczny materializm, naturalizm i ewolucjonizm przygotowały paradygmatyczny uskok, który dobitnie wskazał Fryderyk Nietsche. W odpowiedzi na radykalną zmianę poczucia sensu rzeczywistości rodzi się, z jednej strony, dekadencki nihilizm, z drugiej - odradzaja się alternatywne systemy religijne oraz ezoteryka ${ }^{1}$, traktowana jako ponętna forma komunikacji ze zdegradowanym przez myśl filozoficzną transcendentalnym sacrum.

Twórczość Przybyszewskiego, który był nadzwyczaj wrażliwy na przemiany cywilizacyjne, wyczulony na ich podziemne prądy, znakomicie oddaje stan anomii, w jakim znalazło się nowoczesne indywiduum, pozbawione egologicznej podmiotowości, systemu aksjonormatywnego i perspektywy wieczności. Polski pisarz, który katolicyzm miał niejako „zakodowany we krwi” (ślady tłumionej religijności przebijają przez cała jego twórczość), dojrzewający artystycznie w europejskiej przestrzeni w wielokulturowej berlińskiej metropolii - mocno reagował na ledwo rozpoznawalne symptomy choroby ówczesnej kultury. Obecne w jego

\footnotetext{
${ }^{1}$ Przypomnijmy, że koniec XIX w. to okres rozwoju tajnych stowarzyszeń i rozkwitu ezoterycznej wiedzy, zwłaszcza w Paryżu, m.in. w kręgu C. Debussy’ego, w którym obracali się S. Mallarmé i J. Péladan, twórca Zakonu Katolickiego Różanego Krzyża, Światyni i Graala (założonego w 1890 r.; zakon ten uniknął papieskiego potępienia). Debussy (który powiadał, że Przybyszewski należy do jego ulubionych pisarzy) przyjaźnił się ze S. de Guaita, czołowym satanistą epoki i założycielem Kabalistycznego Różanego Krzyża (1888). W tym okresie powstało też najsłynniejsze brytyjskie towarzystwo okultystyczne, Zakon Złotego Świtu (1887), założone przez M.G. Mathersa, szwagra H. Bergsona (członkiem tego zakonu był przez jakiś czas A. Crowley, najsłynniejszy satanista XX w.). Powstaje też coraz więcej rozmaitych ugrupowań okultystyczno-teozoficznych, nawiązujących do założonego w Nowym Jorku przez H. Bławatską Towarzystwa Teozoficznego (1875). Pod koniec XIX w. odżywają także herezje katarskie, w 1890 r. powstał w Langwedocji Kościół neokatarski (założony przez J. Doinela i Papusa), który spotkał się z ostrym potępieniem papieskim.
} 
twórczości blasfemie i demonomanie są ekspresja pankosmicznej traumy, wyrażają wewnętrzną psychomachię epoki, rozgrywającą się między sakralnością, będącą w stanie utraty i nihilistycznymi prądami, podmywającymi jej fundamenty ${ }^{2}$.

\section{/// 2. Pakty z szatanem}

Pakt z szatanem - metafora poznania ciemnej strony egzystencji zawarł Przybyszewski już we wczesnej fazie twórczości, kiedy w Królewskiej Bibliotece Berlińskiej zgłębiał pisma dawnych mistyków, teologów, teozofów i alchemików, m.in. Pierra Abelarda, Bernharda z Clairvaux, Awerroesa, Jeana Bodina, Remigiusza, Alphonsa de Spiny, Jakuba Sprenglera (zwłaszcza słynne Malleus Maleficarum), studiowal protokoły z procesu czarownic, a także czytał dzieła współczesnych mu okultystów i diabologów, takich jak Éliphas Lévi, Johan Joseph von Görres, Jules Michelet, Papus, Leo Taxil, Stanisław de Guaita, Karl Kiesewetter i wielu innych. Intensywne studia z zakresu satanizmu zaowocowały obszerną rozprawa nt. historii kościoła szatana (Przybyszewski 1997b) 3 i usytuowały Przybyszewskiego w pozycji czołowego „niemieckiego satanisty” (por. Matuszek, 1996, w różnych miejscach), któremu powierzono redakcję ezoteryczno-okultystycznego pisma „Metaphysiche Rundschau”". Problemat szatańskości (demoniczności) świata zajmował Przybyszewskiego przez całe życie - jego ostatnim literackim tekstem będzie demonologiczna powieść Il regno doloroso (1923), osnuta wokół słynnego procesu czarownic, jaki miał miejsce w baskijskiej prowincji Labourt w 1610 r., w której postawione zostaje fundamentalne pytanie o ontologiczny status człowieka i teologiczna strukturę świata.

Dialog z koncepcjami ontologicznego nihilizmu („świata bez Boga”) Przybyszewski prowadzi, wykorzystując satanistyczno-gnostyckie fantazmaty, które umożliwiają mu werbalizację trwogi przed metafizyczną pustką i pozwalają uporządkować absurd i chaos świata, przyporządkowując zło sferze materii. Teologia gnozy, która u początków wszechświata dostrzega kosmiczną katastrofę (rozpad pierwotnej Jedni, boskiej pleromy), pozwala wskazać przyczyny zła i wyjaśnić fiasko teodycei, a także wytłumaczyć

\footnotetext{
${ }^{2}$ Niektóre z zawartych w tym tekście tez mają szersze rozwinięcie w mojej książce (Matuszek 2008).

${ }^{3}$ Die Synagoge des Satans. Ihre Entstehung, Einrichtung und jetzige Kritik, Berlin 1897. Znamienne, że w Polsce opublikowane zostały tylko fragmenty książki: w „Życiu” $1899 \mathrm{nr} 4$ i 5 (Synagoga szatana. I. Powstanie $i$ tworzenie, z powodu druku tej rozprawy numer 5 skonfiskowany został przez cenzurę) oraz w „Młodości” 1900 z. 2. W tłumaczeniu autora ukazała się także zmieniona wersja innego fragmentu niemieckiego oryginału, zatytułowana Synagoga szatana. Praycrynek do psychologii cæarownicy, Warszawa 1902. Całość została udostępniona w przekładzie na język polski (autorki niniejszej książki) dopiero w sto lat po jej napisaniu (w publikacji: Przybyszewski 1997b).

${ }_{4}^{4}$ Po przejęciu pisma przez R. Wrede i przekształceniu go w „Metaphysische Rundschau” właśnie Przybyszewskiemu powierzono stanowisko redaktora, które sprawował od lipca do września $1897 \mathrm{r}$.
} 
źródło pierwotnego, archetypicznego lęku, przypisanego kondycji ludzkiej, bardzo mocno odczuwanego w epoce fin de siècle'u.

Jak słusznie zauważyła Agata Bielik-Robson, zawierzenie głoszonemu przez gnozę lękowi prowadzi do pomylenia „odrazy do bytu doczesnego z pragnieniem duchowości” (Bielik-Robson 2000: 321) i sprzyja spekulacjom metafizycznym, opartym na repulsji wobec bytu i istnienia. Taką inwersyjną konstrukcją zdaje się być satanizm Przybyszewskiego, uruchamiający heretycki ,archetekst”, zbudowany na gnostycko-manichejskim micie dobrego i złego boga ${ }^{5}$, nicujący semantykę wielkiej fabuły chrześcijaństwa. W swej satanologicznej rozprawie polski autor tworzy mitohistorię satanizmu od czasów średniowiecznych po współczesne, próbując udowodnić, że był on skrajną inwersją religii judeochrześcijańskiej i konsekwencją rozwoju instytucji Kościoła, który narzucił ideał uległości i naśladowania, a tym samym stłumił naturalną witalność człowieka. Wprowadzenie celibatu, wykluczenie kobiety, religijne i instytucjonalne restrykcje „grzechu” miały - jego zdaniem - działanie patogenne i wywołały nie tylko powrót do archaicznych wierzeń i obrzędów, ale także transgresyjnych zachowań.

Polski modernista zapewne podpisałby się pod stwierdzeniem Jeana Baudrillarda, że „wszystko, co wyzbywa się swej części przeklętej, przypieczętowuje własny zgon" (Baudrillard 2009: 119), bowiem energia Zła jest konieczna dla wewnętrznej równowagi świata. Fiksację Przybyszewskiego na psycho- i onto-patologie można więc traktować jako rozpaczliwą próbę scalenia rozpadającego się świata. Zło i jego bóg, szatan, staje się ważnym przedmiotem literackich eksploracji. Należy jednak podkreślić, że figura szatana jest u Przybyszewskiego bytem wielofunkcyjnym, oznacza bowiem zarówno boga ciemności (złej materii) i demona nierządu (płciowych orgii), jak i metaforę pozytywnego buntu, intelektualnej anarchii, twórczej dynamiki życia.

Można powiedzieć, że eksploracją królestwa szatana, jakiej podejmuje się Przybyszewski, steruje nowożytna, faustyczna ciekawość poznawcza, za którą kryje się narkotyczne pragnienie poznania przez zło (por. Riceur 1986). Główną przestrzenią transgresywnych penetracji staje się pierwotna przestrzeń sabatu, jeszcze nie poddana kulturowej represji i ekskluzji. Jean Baudrillard napisze sto lat później, że „orgia stanowi eksplozywny moment nowoczesności, moment wyzwolenia, dokonującego się we wszystkich możliwych sferach" (Baudrillard 2009: 5), które prowadzi do wyzwolenia

\footnotetext{
${ }^{5}$ Przybyszewski pisze w pierwszym akapicie swojej rozprawy: „Istnieją dwaj odwiecznie przeciwstawieni sobie bogowie, dwaj stwórcy i dwaj władcy, bez początku i końca. Dobry bóg stworzył duchy, czyste istoty. Jego królestwo jest niewidzialne i doskonałe, nie zna ni walki, ni bólu. Zły bóg stworzył świat widzialny, cielesny, przemijający. Stworzył ciało i namiętność, ziemię z jej walką, cierpieniem i rozpacza, niezmierzony padół płaczu. Stworzył naturę, która wytwarza tylko ból, rozpacz i zbrodnie" (Przybyszewski 1997b: 158).
} 
politycznego, seksualnego, rozmaitych mocy destrukcyjnych i nieświadomych popędów, a w konsekwencji do zaniku wartości. Przybyszewski był jednym z pierwszych, który w orgii dostrzegł wyzwolenie, prowadzące ku totalnej destrukcji i rozpoznał, że nowoczesne doświadczenie życia jest potworne, „człowiek orgiastyczny”, zredukowany do popędu seksualnego i popędu śmierci, a świat dotknięty nicestwieniem.

Fantazmaty satanistyczne poddane zostaja w jego tekstach (przede wszystkim w Synagodze szatana i powieści Il regno doloroso) „naukowej” wizualizacji ${ }^{6}$. Przybyszewski na podstawie wielu źródeł rekonstruuje przebieg sabatu i wizerunek boga ciemności, co warto tu przytoczyć ze względu na malarską precyzję odtwarzania szatańskiego symulakru:

Od kolan ma nogi kozła ohydnego z kopytami. Twarz czarnego, obrosłego kozła, dwa olbrzymie rogi wyrastaja na głowie, a między nimi pali się ogromna pochodnia, której łuna oświeca cały sabat. Oczy, osadzone w głębokich dołach, jarzą się jak rozpalone węgle. Gdy pysk otworzy, jest jak głęboka jama, z której się dymy siarki wydobywają. Piersi ma kobiece, które aż do brzucha zwisaja, jedno ramię grube i męskie, drugie miękkie, okragłe i kobiece, brzuch pokryty jest łuskami i odgraniczony od piersi jakby jakąś krwawoczerwona tęcza, a u ramion ma dwa olbrzymie skrzydła nietoperza (Przybyszewski 2003a: 79).

Diabelski wizerunek, jaki rysuje jedna z czarownic z powieści Il regno doloroso, przypomina androgynicznego szatana z kompozycji symbolicznych Heinricha Khunratha, wywodzących się z kabały. Równie szczegółowe i oparte na satanologicznych źródłach są opisy sabatu, począwszy od przygotowań czarownicy do udziału w sabatowych transgresjach, poprzez stenogram celebracji szatańskiej mszy, po zapisy orgii. Przybyszewski, doskonale zaznajomiony $z$ satanistyczną literatura, inkrustuje swe relacje „autentycznymi” cytatami, np. formułą zaprzysiężenia, jaką składa neofita bogu ciemności podczas sabatu:

Zapieram się Boga, Jezusa Chrystusa, Ducha Świętego, Najświętszej Marii

Panny, Wszystkich Świętych, Świętego Krzyża. Oddaję się cały twej potędze.

Nie będę miał innego boga nad tobą, ponieważ ty jesteś moim bogiem, a ja twoim służebnikiem (Przybyszewski 1997ba: 203).

Przymierze z szatanem oparte zostaje na inwersji Dekalogu i skrajnej negacji chrześcijańskich wartości:

Neofita całuje Szatana w twarz położona poniżej pępka i w ten sposób oddaje się w wieczną niewolę i absolutne władanie Zła. Diabeł zeskrobuje z jego czoła znamię chrztu świętego, a następnie w brudnej chrzcielnicy odbywa

\footnotetext{
${ }^{6}$ Modernistyczny „satanista” wierzy w sabaty, podobnie jak Michelet w Czarownicy (1862), a także niektórzy późniejsi historycy Np. M. Summers, The History of Witchcraft and Demonology (1926), A. Runeberg, Witches, Demons and Ferlity Magic (1947), J. Russel, Witchcraft in the iddle Age (1972). Trwające prawie trzy stulecia (od końca XIV aż do początków XVII w.) represje przeciw czarownicom budziły już zainteresowanie romantycznych historyków.
} 
się nowy chrzest, podczas którego nowicjusz przysięga nie przyjmować sakramentów, chyba że do nieczystych celów, opluwać i zohydzać święte relikwie, strzec tajemnic sabatu, pozyskiwać nowych członków szatańskiego kościoła i oddawać Szatanowi wszystkie swoje siły. Uwieńczeniem całej ceremonii jest straszliwa prośba chrzczonego, by Szatan wymazał go z księgi żywota i wpisał w księgę śmierci. Diabeł naznacza jego ciało stygmatami na powiekach, ramionach, wargach, kobiety otrzymują diabelskie piętno na sutkach i wargach vaginy (Przybyszewski 1997a: 204).

Szatańska liturgia opiera się na profanacji świętości, organizują ja zasady transgresji i inwersji oraz estetyka potworności i blasfemii ${ }^{7}$. Sabat jest wyklętą ekstazą, doświadczaniem anty-raju (,sabat jest istotnym rajem, a rozkoszy, jaką daje, wysłowić nie można" Przybyszewski 2003a: 73), erupcją negatywnego żywiołu, prowadzącego do (samo)zatraty. Szatańskie królestwo jawi się jako świat bluźnierczego, nonsensownego kontrtekstu, perwersyjnego zatracenia:

Orgia przeradza się w tych najdzikszych skokach w szaleńcze rozpasanie. Wyzwolona została bestia w człowieku, namiętne pożądanie stapia się z żądzą krwi, obłęd rozkoszy rozpala się w delirium bólu, które przechodzi w odurzenie. Taniec powoli wygasa, ludzie rzucają się na siebie, mężczyźni i kobiety, bez różnicy, ojciec na córkę, brat na siostrę, mężczyzna na mężczyznę, i wszyscy tarzają się w najplugawszym nierządzie, jak psy leżą jedni na drugich, zdrętwiali w konwulsyjnych skurczach iż coraz straszliwszym jękiem nieludzkiej, bolesnej kopulacji wydobywa się z nich ochrypły ryk: Har! Har! (Przybyszewski 1997a: 201-202).

Sabat pokazany jest jako antyrzeczywistość, wyzwalająca zwierzęce instynkty w człowieku, przeżywana w histero-epileptycznym transie, wywołanym hipnogennymi narkotykami i konwulsyjnymi ruchami ciała. To zwrócenie uwagi na wewnętrzny związek między horyzontem doświadczeń seksualnych a śmiercią - unicestwieniem Boga wyprzedza konstatacje Georges'a Bataille'a i Michela Foucaulta ${ }^{8}$.

Królestwo szatana jest ,samopożerającą się witalnością” (por. Gutowski 2001: 284), co znalazło symboliczny wyraz w scenie uśmiercenia noworodka przez wepchnięcie go do kobiecych narządów rodnych. Przestrzeń orgii destruuje porządek kultury, dokonuje nicestwienia wszelkiego sensu, wyzwala regresywną transgresję prowadzącą do śmierci.

\footnotetext{
${ }^{7}$ Przestrzeń sabatu jest przestrzenią profanacji chrześcijańskich rytuałów i wszelakich zbrodni: kazirodztwa, dzieciobójstwa, bezczeszczenia ludzkich zwłok. Przybyszewski przywołuje szereg przykładów, potwierdzających sabatowa ,antyrzeczywistość”, takich jak kropienie „wiernych” stęchła gnojówka, odurzanie się smrodliwym dymem z trujących ziół, wywołującym konwulsje, całowanie szatana w miejsce skryte pod ogonem, przyjmowanie hostii sporządzonej z ropuch i krwi dzieci, naśladowanie zwierzęcych zachowań itp.

${ }^{8}$ Foucault pisze, powołując się na Bataille’a: „Być może ważność seksualności w naszej kulturze [...] bierze się z jej nierozłącznego związku ze śmiercią Boga" (Foucault 1999: 49).
} 
W „diabologicznych” tekstach Przybyszewskiego ukryta jest jeszcze inna, ważna supozycja: pytanie o to, czy szatan (i sabat) naprawdę istnieje, czy jest tylko symulakrem, złudnym tworem przerażonej wyobraźni, kłamstwem zastępującym pusty znak boskiej (nie)obecności. W powieści Il regno doloroso w maski średniowiecznych inkwizytorów przebrał się podmiot nowoczesny, który rozlicza Boga i lituje się nad marnością świata, jaki stworzy1 ${ }^{9}$. Sędzia-inkwizytor, w nic nie wierzacy cynik i „literat”, rozpoznaje w sabacie przestrzeń imaginacyjna - piekło indywidualnej i zbiorowej nieświadomości. Odkrywa, że sabat jest tylko symbolem missa desperationis oszalałej ludzkości, wizualizacją ontologicznej i egzystencjalnej „nędzy” i wynikającej z niej rozpaczy.

Szatańska przestrzeń orgii nie zanika wraz z rozwojem kultury i naporem racjonalizmu, lecz podlega, zdaniem Przybyszewskiego, dalszym transformacjom: w czasach nowoczesnych przekształca się w „czarne msze" 10 , tingel tangle, a zwłaszcza diabelskie ideologie, zaczadzające umysły. Swą satanologiczną rozprawę kończy supozycją, że szatan zagraża także współczesnej kulturze. Figurę szatana można traktować zatem jako ostrzeżenie przed demonami nowoczesności, takimi jak toksyczne demoniczne ideologie (nihilizm i anarchizm), diabelskie patologie (demony lęku, pychy i obłędu), szaleństwa ciała i duszy (demony płci i sztuki).

\section{/// 3. Demony nowoczesności - nihilizm i anarchizm}

Przybyszewski obnaża dwie najbardziej zagrażające ideologie, jakie zrodziła nowoczesność: nihilizm i anarchizm (o którym pisał w „Gazecie Robotniczej”, że jest „,czystym obłąkaniem”; Przybyszewski 1892), które zdiagnozowane zostaja przez niego jako niebezpieczne narzędzia w rękach „złego boga” - prolog przeczuwanej Apokalipsy. Diabelski bohater Drieci szatana, który wyciagnie ostateczne konsekwencje z nauk głoszonych przez rewelatorów epoki (Stirnera i Nietzschego), dokona rzeczywistego odwrócenia wszystkich wartości. Gordon chce zniszczyć świat dla czystego acte gartuit. „Zniszczenie jest moim dogmatem, moją wiarą,

\footnotetext{
${ }^{9}$ Warto zaznaczyć, że spod demonologicznych opisów boga ciemności prześwituje dekadencki obraz smutnego szatana, cierpiącego, znudzonego, przepełnionego melancholią: „Wyglądał zmęczony, jakby z tortur zdjęty, a cały był odziany płomieniami [...]. Przemawiał głosem nieartykułowanym, bardzo znudzonym, nie mniej jednak rozkazującym i tak strasznym, że wszystko naokół drżało. A jednak głos był przepełniony, jakgdybygłębokim smutkiem, a cała jego postać wyrażała dumę wysokiego, ale melancholijnego dostojnika, który jest ustawicznie znudzony" [podkr. GM] (Przybyszewski 2003a: 79).

${ }^{10}$ Przybyszewski relacjonuje przebieg tych szatańskich ceremonii, które zaczynały się od celebracji katolickiej mszy nad nagim kobiecym ciałem, utoczeniem krwi do kielicha z szyi zabijanego dziecka i „wypatroszeniem” jego ciała. Następnie kapłan mieszał krew z winem i hostią sporządzoną ze spalonych ciał dziecięcych. Po konsekracji i przyjęciu tej blasfemicznej komunii następowała seksualna orgia (Przybyszewski 1997b: 219-220).
} 
„Całe miasta, całe prowincje, cały kraj, świat cały zniszczyć - to dopiero będzie prawd ziw y m szczęściem” (Przybyszewski 1993: 7, 156).

Demon nihilizmu zaczadza umysły bohaterów Przybyszewskiego. Jego źródłem jest ontologiczna rozpacz, nienawiść oraz uczucie obrzydzenia wobec świata:

Przecież ty szerzysz zniszczenie jedynie tylko dlatego, że nosisz w sobie całe piekło nieszczęścia i obrzydzenia. Nie, nie obrzydzenia - obrzydzenie osłabia i pęta energię, ale nienawiści - nienawiścil Nigdy nie wyobrażałem sobie, by człowiek mógł tak chorobliwie nienawidzieć... (Przybyszewski 1993: 95)

- powiada o Gordonie Ostap, jego alter ego.

Przybyszewski pokazuje, że źródłem szatańskiej pandestrukcji nie są (lub nie tylko) społeczno-polityczne uwarunkowania, lecz histeryczna nienawiść do społeczeństwa i jego instytucji. Anarchistyczny akt podporządkowany jest zewnętrznym i wewnętrznym przymusom (kompleksom). Terror w Dzieciach szatana zdiagnozowany zostaje jako zastępcza reakcja na zahamowane libido ${ }^{11}$ i pokazany jako paranoiczna idea, która łatwo zakaża „wykluczonych”, ówczesnych homo sacer (używając terminu G. Agambena: 2008):

Każdy trawiony lękiem, każdy zrozpaczony, co zgrzyta zębami w bezsilnej wściekłości, każdy, kto ociera się o więzienie, każdy, kto głód znosi i upokorzenie, niewolnik i pan syfilityczny, nierządnica i zhańbiona dziewczyna, opuszczona przez kochanka, więzień i złodziej, literat bez powodzenia i aktor wygwizdany - wszyscy oni są m o i ! Pomagają mi w pracy. Oni szerza rozpacz, bunt i wzburzenie. [...] Oni wszyscy, my wszyscy spojeni jesteśmy tym jednym łącznikiem, tą jedną zbrodnią: rozpaczą. Jeden nie zna drugiego, ale wszyscy jesteśmy braćmi (Przybyszewski 2003: 50).

Nowoczesny Antychryst bez trudu gromadzi wokół siebie współczesne „dzieci szatana”. Ruch anarchistyczny pokazany zostaje jako przejaw działalności szatana, kolejny krok zmierzający do unicestwienia świata. Stirnerowski indywidualistyczny anarchizm staje się w ujęciu polskiego pisarza anarchizmem metafizycznym - satanizmem.

Nihilizm pojęty w aspekcie ontologicznym zakłada, że sam byt dotknięty jest „nicestwieniem”, rozpada się, staje się ,,anarchiczny”. Bycie jawi się jako osłabnięcie i zniknięcie. Taki scenariusz zagłady realizuje się w Drieciach nędzyy (1913), jednej z bardziej interesujących powieści Przybyszewskiego. Dzieło szatańskiej pandestrukcji rozgrywa się tu w trzech planach: indywidualnej autodestrukcji obłąkanych bohaterów, zniszczenia rodzinnego gniazda,

\footnotetext{
${ }^{11}$ Cierpienie Gordona wynika bowiem z braku zaspokojenia potrzeby aktu defloracji, ponieważ jego ukochana należała wcześniej do innego mężczyzny. Obsesja virgo intacta (dręcząca niemal wszystkich bohaterów Przybyszewskiego) w Di̛ieciach sæ̨atana przekształca się w manię niszczenia. I to zwrócenie uwagi na dialektyczne połączenie popędu erotycznego i agresji wyprzedza o wiele lat odkrycia Freuda. Pisałam o tym szerzej w szkicu Nedza świata bez Boga. O „Dzieciach szatana” Stanisława Pryzbyszewskiego (Matuszek 1993).
} 
symbolu rodzaju ludzkiego, oraz projektu unicestwienia świata ${ }^{12}$. Zwłaszcza te dwie ostatnie metafory zagłady są szczególnie interesujące. Ród Krywłów, naznaczony preontologiczną skazą istnienia, staje się wzorem - znakiem rodzaju ludzkiego, stworzonego i porzuconego przez BogaOjca, złośliwego demiurga, który łudzi człowieka mirażem nieistniejących rajów. Blasfemiczny bunt wobec „podejrzanego" Stwórcy przeradza się w nihilistyczną konstatację boskiego oszustwa i odkrycie, że Raj jest symulakrem, gatunek ludzki skażony patologia, a życie szaleństwem.

\section{/// 4. Demony Ja}

Utwory Przybyszewskiego przełamuja społeczne tabu nie po to, by epatować odbiorcę, lecz rozpoznać to, co wykluczone i „inne”, „niesamowite" i demoniczne, a co ujawnia się poprzez osobowości zdezintegrowane, dręczone przez upiory i sobowtóry, poddawane wewnętrznym psychomachiom. Freud, to co wyparte przez świadomość i powodujące uczucie dziwności istnienia, określił jako Niesamowite (das Unheimliche). Przybyszewski ową „dziwność” ujmuje w bardziej uniwersalnych, archetypicznych kontekstach (antycypujących teorie Junga i Lacana). Psychoanalityczna szkoła Freudowska twierdziła, że zachowanie człowieka wymuszone jest przez moce nieświadomości, które są irracjonalne i amoralne. Przybyszewski dodaje, że są d e m o ni c z n e. Odkrywa, że człowiek nowoczesny ma w sobie pokłady obcości („To coś obcego, znajdującego się poza mną"; Przybyszewski 1997a: 69), jest podmiotem chorym, zdecentrowanym, doświadczającym nieustannego rozpadu.

De(kon)strukcja symulowanego cogito (obnażenie mistyfikacji świadomości) przybiera postać destruującej eksplozji, na zgliszczach której pozostają tylko negatywne uczucia i instynkty: rozpacz, lęk, nienawiść, żądza niszczenia. Można powiedzieć, że w utworach Przybyszewskiego ujawnia się to, co Hugo Ball wiele lat później nazwie ,anarchią wyzwolonych demonów"13, a co było rezultatem załamania się symbiotycznej relacji między stabilną jaźnią i uporządkowanym światem.

\section{/// Demon pychy}

Megalomania jest pierwszym wyrazistym sygnałem podmiotowości bohaterów Przybyszewskiego. Lucyfer, demon pychy, przebiera się w różne maski, kusząc bohaterów, jak biblijny wąż, obietnicą transgresyjnego

\footnotetext{
12 Interesującą interpretację Džieci nęzry jako scenariusza zagłady rodu ludzkiego przeprowadził W. Gutowski (Gutowski 2008).

13 Jest to określenie H. Balla użyte w wykładzie o W. Kandinsky'm (Hugo Balls Vortrag über Wassily Kandinsky in der Dada in Zürich am 7.4.1917, „Deutsche Vierteljahresschrift für Literaturwissenschaft und Geistesgeschichte”, t. 51, 1977, s. 689).
} 
poznania. Stirnerowskie „Ja jestem Ja” urasta do megalomańskiego grandiose self, które całą libidalną energię angażuje w narcystyczną kontemplację siebie i wyłonionych z lustra Ja wielkościowych fantazmatów (idealnej kochanki, wewnętrznego Boga czy też megadzieła). Tak jak w mitologenie grzechu pierworodnego, opisanym w trzecim rozdziale Księgi Rodzaju, człowiek daje się oszukać demonowi pychy i zaczyna wierzyć w swą wszechmoc.

Przybyszewski zdaje się być blisko rozpoznania „syndromu Narcyza”, jaki rodził się u progu nowoczesności. Niemal wszyscy jego męscy bohaterowie kierują libido na własne ego, tamując w ten sposób możliwość afirmującego kontaktu ze światem i z samym sobą (por. Lowen 1995). Demon pychy i fałszywego samozachwytu prowadzi te postaci poprzez niszczenie innych i świata do autodestrukcji.

\section{/// Demon sztuki}

Można rzec - pomijając wszystkie inne konteksty i interpretacje - że koncepcja sztuki, jaką głosił Przybyszewski, zrodziła się z lucyferycznej pychy. Autor Confiteor przeświadczony był, że sztuka umożliwia poznanie absolutne, jest transmiterem treści pozaracjonalnych i pozasemiotycznych - ma potencję rozpoznania ,istoty bytu”. Wierzył również w status artysty jako boskiego demiurga, nawiązującego kontakt z treściami uniwersum i stwarzającego nowe światy. Znaczące, że pod koniec życia ta idée fixe poddana została ostatecznej falsyfikacji. W jednej z najlepszych swych powieści, ekspresjonistycznym Krayku (1917), kreuje postać malarza, który pragnie stworzyć mega-dzieło, przedstawiające syntezę życia i śmierci i odsłaniające metafizyczny fundament bytu. Artysta chce namalować obraz mający być „potężną syntezą ulicy”, rozumianej jako symbol esencji życia, eksplozje barw przekształcić w transmiter treści, pochodzących $\mathrm{z}$ universum semanticum.

Epifanijne przeżycie „krzyku śmierci”, jakiego malarz doznaje, widząc samobójczy skok prostytutki, uruchamia jego twórczą obsesję. Krzyk topielicy staje się dla niego kolektorem wglądu w transcendentne przestrzenie bytu, nasyca artefakty silną emocjonalnością i ma umożliwić oddanie „,nagiej prawdy” ludzkiej egzystencji. Epistemologiczny i estetyczny „głód” kieruje go ku ostatecznym transgresjom - zbrodni na Innej i na sobie samym oraz odsłania swą fantazmatyczną postać w chwili śmierci.

Nowoczesny artysta nie jest w stanie stworzyć epifanijnego pejzażu krzyku, nie udaje się transpozycja momentalnego doświadczenia w sferę ikoniczna, nie zostaje zrealizowany koncept sztuki obdarzonej gnoseologiczną potencją ostatecznej syntezy. Artysta maudit słyszy ów eschatologiczny krzyk dopiero w momencie zabicia swego psychosobowtóra - czyli siebie samego. Sztuka, która pragnie oddać demoniczne, transgresyjne 
i ekstatyczne doświadczenie bytu, musi łączyć się - jak zdaje się sugerować Przybyszewski - z (samo)unicestwieniem.

\section{/// Demon płci}

Także życie, zachłanne w swej libidynalnej eksplozji, zmierza na skraj przepaści. Demon płci rządzi nie tylko bohaterami utworów Przybyszewskiego, ale całym światem, zgodnie z koncepcją ontogenezy z płci, jaką twórca zaprezentował już w pierwszym swym literackim tekście, Totenmesse („Na początku była chuć”14). Cielesność, artefakt materii - królestwa szatana, jest elementem unicestwianym (przymus śmierci) oraz unicestwiającym (więzieniem duszy). Bohaterowie Przybyszewskiego uwikłani są w aporetyczne relacje z własna płciowością. Sexus fascynuje i przeraża, a często budzi manichejski wstręt i lęk przed kobietą jako emisariuszką szatana, wciagającą mężczyznę w piekło grzesznej materii.

Jak pisze A. Lowen, ,nasze osobiste piekło tkwi głęboko w trzewiach ciała, w jamie miednicznej, gdzie znajduje się nasza zakuta w kajdany seksualność" (Lowen 1992: 164). To piekło przedstawione zostało już w utworach Przybyszewskiego, w których autor niejednokrotnie sięga do „szatańskiego” sztafażu (wampiryczność, sukkubat, orgiastyczność). Podmiotem sabatowych orgii jest przecież seksualne ciało, Królestwem Szatana - światem „złej” materii - rządzi Chuć ${ }^{15}$.

Ciało naznaczone płciowościa jest ciałem asemantycznym, zdekomponowanym przez demony popędów i zahamowań. Czasem owe demony ujawniają się w histerycznej eksplozji, która jest szyfrem kulturowego dyskomfortu i wielorakiego zranienia: sfery symbolicznej (osaczenie przez społeczne i kulturowe więzy), tożsamości (rozbicia spójnego Ja i niepewności płciowej), a zwłaszcza „rany” ciała skazanego na przemijalność i śmierć.

Teksty Przybyszewskiego pokazuja, że język histerii był uniwersalna, ponadpłciową formą przekazu, której ulegał także męski podmiot. Jego bohaterowie czują w sobie jakiś podziemny wulkan, który nieustannie

\footnotetext{
${ }^{14}$ Totenmesse opublikowana została w Berlinie w 1893 r., polski przekład, zatytułowany Requiem aeternam, ukazał się w wersji czasopiśmiennej w 1900 r., a w wydaniu ksiażkowym w 1904 we Lwowie. Utwór rozpoczyna cytowane zdanie, otwierające koncepcję ontogenezy z płci. Szerzej piszę o tym w książce Stanisław Pryybyszenskei - pisarz nowoczesny. Eseje i proza - próba monografii, (rozdział: Nowoczesna msza żatobna).

${ }^{15} \mathrm{~Np}$.: „Do jej największych rozkoszy należało mieszanie ciała Jezusa do brudnych maści, wpychanie go do organów płciowych" (Przybyszewski 1997b: 198). Por. opis orgiastycznego masakrowania dzieci. Przybyszewski pisze, że czarownica jest „straszliwie okrutna, nie zna żadnej litości, tylko ekstatyczną żądzę zadawania cierpienia. Kocha okrucieństwo i jej seksualne pożądanie zawsze jest z nim związane. Sadyzm i masochizm opanowały jej chuć, ale nie wystarcza jej chłostać i być chłostana. Trochę zadowolenia odczuwa dopiero wówczas, kiedy wgrzebuje się chciwymi rękoma we wnętrzności zamordowanego dziecka, gdy rozrywa zębami jego pierś, by wydrzeć stamtąd drgające, jeszcze ciepłe serce, kiedy może wrzeszcząc z rozkoszy tarzać swój goły zadek w otwartej jamie brzuszneje (Przybyszewski 1997b: 197).
} 
wybucha, a jego eksplozje są nieobliczalne, destruujące zarówno otoczenie, jak i sam histeryczny - demoniczny podmiot. Uobecniona w twórczości autora De profundis histeria odsłania kryzys męskości i pokazuje siłę demona lęku nie tyle przed śmiercią, ale głównie przed życiem („,przymusem życia”).

\section{/// Demon lęku}

Przybyszewski pisał wręcz o „psychozie przerażenia” jako egzystencjalnej sygnaturze swoich czasów. Polski autor już w 1893 r. zauważył (w Totenmesse - Requiem aeternam), że nowoczesny człowiek doświadcza lęku przed głębia - przed tajemnicą istnienia. Freud wiele lat później stwierdzi, że lęk to cień odczarowania, które tylko z pozoru kroczy w pełnym świetle rozumu. „Chory” i ,szalony” podmiot Przybyszewskiego w poczuciu zagrożenia nicością sięga po mity o(s)calającej miłości (idea fixe Androgyne) i język gnostyckich herezji. Uniwersum posiada wszak gnostycką (szatańska) ontyczną strukturę. Przybyszewski, podobnie jak współcześni interpretatorzy, zainspirowani jungowską psychologia głębi, wiąże pierwotny lęk, pojawiający się w momencie narodzin, z mitami kosmogonicznymi i antropologicznymi, przedstawiającymi narodziny świata i człowieka jako wynik rozpadu boskiej pleromy. Bohaterowie Przybyszewskiego cierpią z powodu separacji od Matki - indywidualnej i zbiorowej rodzicielki (Chuci) ${ }^{16}$. Dręczy ich egzystencjalny lęk, niczym niedający się ukoić, nawet odurzeniem. Jest to bowiem lęk przed kulturową i eschatologiczną katastrofa, i zagrożeniami, jakie niesie ze sobą „martwa transcendencja”. Tkwienie w kleszczach lęku prowadzi do indywidualnego i zbiorowego obłędu.

\section{/// Demon obłędu}

Przybyszewski wyczuwał (jak później surrealiści), że nerwice i psychozy stanowia najbardziej wyraziste ekspresje ukrytych szyfrów kultury. Kody te próbował złamać lub przynajmniej rozpoznać. Wszyscy jego bohaterowie sa ch or zy. Przybyszewski sugeruje, że wgląd w istotę bytu daja tylko stany anormalne. W swych utworach przedstawia osobowości zdezintegrowane, transgresywne, znajdujące się w nieustannym alkoholowym transie, dręczone przez zwidy, majaki i upiory, jakby demon obłąkania opanował ich umysły i dusze. Zamiast charakterów społecznie aprobowanych pojawiaja się osobowościowi dewianci, zredukowani do poziomu psychoanalitycznego („eksplodujące podświadomości”), a ich urojenia przybierają realne kształty, kompleksy treści nieświadomych inscenizują psychosobowtóry, destrukcja Ja przyjmuje formy wewnętrznych

\footnotetext{
${ }^{16}$ Szerzej piszę o tym w książce Stanisław Praybysz̨ewski-pisarz nowoczesny (Matuszek 2008).
} 
psychomachii. W utworach tego niedoszłego psychiatry można znaleźć niemal kliniczne opisy nerwicowych zaburzeń i psychicznych schorzeń, takich jak narcyzm, melancholia, sadomasochizm, narkolepsja, paranoja, schizofrenia, Dämmerungzsustände itp.

Bohaterowie Przybyszewskiego toczą schizofreniczne zapasy z fundamentalnymi treściami kolektywnej - kulturowej (nie)świadomości, ożywianymi w procesie rozpadu osobowości. Demoniczne „obłąkanie” polski twórca ukazywał w wymiarze indywidualnym i zbiorowym. Jego powieści (zwłaszcza Drieci szatana i Dqieci nedsy) przynoszą psychoanalityczne i ontologiczne diagnozy upadku obłąkanej rodziny ludzkiego rodu, które można uznać za jeden z bardziej interesujących, katastroficznych dokumentów „zbiorowego obłędu”, pokazujących, że ludzkość skażona jest ontyczną i antropologiczną „patologią”, życie więc musi być szaleństwem.

Zarazem jednak demonizm Przybyszewskiego jawi się jako subwersja pragnienia żarliwej wiary, sui generis „,teologia rozpaczy”, będąca odpowiedzia na nihilizm epoki i katastrofizm ontologiczny, jaki coraz wyraźniej rysował się na horyzoncie nowoczesności. Figura szatana, obecna w jego eseistyce i twórczości, jest negatywnym stygmatem współczesności, ostrzegającym przed konsekwencjami odczarowania świata. Jego twórczość oddaje wewnętrzną psychomachię epoki, rozgrywającą się między sakralnością, będąca w stanie utraty, i nihilistycznymi prąami podmywajacymi jej fundamenty.

Przybyszewski podejmuje „wielką narrację” chrześcijaństwa w sposób inwersyjny, traktując satanizm jako doświadczenie mistyczne à rebours. Wiara w szatana jest wszak zamaskowaną wiarą w istnienie Boga ${ }^{17}$.

Figurę szatana można czytać jednak także jako formę symulakrum, uznać (co wiele lat później odkryje M. Foucault; por. Foucault 1999: 131), że Szatan nie jest Innym, lecz Tym Samym, a kuszenie toczy się w przestrzeni lustra.

Bibliografia:

/// Baudrillard, J. 2009. Przejraystość zła. Esej o zjawiskach skrajnych. Przeł. Królak, S. Warszawa: Wydawnictwo Sic!.

/// Bielik-Robson, A. 2000. Horror! Horror! Lek jako tabu nowoczesności. W: Taż. Inna nowoczesność. Pytania o wspótczesna formute duchowości. Kraków: Universitas.

\footnotetext{
${ }^{17}$ Piszę o tym szerzej w szkicach: Nędza świata bez Boga. O „Dzieciach szatana” Stanisława Prazybyszewskiego (Matuszek 1993) oraz Międy pustka transcendencïi a szaleństwem zmystów. O wczesnej eseistyce Stanistawa Praybyszewskiego (Matuszek 1997).
} 
/// Foucault, M. 1999. Powiedziane, napisane. Szalensstwo i literatura. Wyb. i oprac. Komendant, T. posł. Markowski, M.P. przeł. Banasiak, B. Komendant, T., Kwietniewska, M., Lewińska, A., Markowski, M.P., Pieniążek, P. Warszawa: Aletheia.

/// Gutowski, W. 2001. Z próżni nieba ku religii ìycia. Motyny chrześsijańskie w literaturze Mtodej Polski. Kraków: Wydawnictwo Literackie.

/// Gutowski, W. 2008. Rodzina jako egzystencjalna pułapka. O „Dzieciach nedzy” Stanisława Prazbyszewskiego. W: Tenże. Konstelacja Praybyszenskeiego. Toruń: Wydawnictwo Adam Marszałek, s. 106-129.

/// Lowen, A. 1995. Narcyzm zapržeczenie prawdziwemu Ja. Przeł. Wojtyszko, P. Warszawa: Jacek Santorski \& CO Agencja Wydawnicza.

/// Matuszek, G. 1993. Nedza świata bez Boga. O „Dzieciach szatana” Stanistawa Praybyszenskiego. W: Przybyszewski, S. Drieci szatana. Kraków: Oficyna Literacka, s. 169-195.

/// Matuszek, G. 1996. „Der geniale Pole?” Niemcy o Stanistawie Praybbyszenskim (1892-1992). Kraków: Universitas.

/// Matuszek, G. 1997. Międy pustke transcendencii a szaleństwem zmystón. O wczesnej eseistyce Stanisława Praybyszenwskiego. W: Przybyszewski, S. Synagoga szatana $i$ inne eseje. Matuszek G. (red.). Kraków: Oficyna Literacka, s. 5-40.

/// Matuszek, G. 2008. Stanistaw Przybyszewski - pisarz nowoczesny. Eseje i proza - próba monografii. Kraków: Universitas.

/// Przybyszewski, S. 1897. Co to jest anarchizm? „Gazeta Robotnicza” 27. /// Przybyszewski, S. 1993. Drieci szatana. Matuszek, G. (red.). Kraków: Oficyna Literacka.

/// Przybyszewski, S. 1997a. Z psychologii jednostki twórczej. II. Ola Hansson. Przeł. Matuszek, G. W: Przybyszewski, S. Synagoga szatana $i$ inne eseje. Matuszek G. (red.). Kraków: Oficyna Literacka, s. 66-89.

/// Przybyszewski, S. 1997b. Synagoga szatana. Powstanie, rozwój i dzisiejsze znaczenie. Przel. Matuszek, G. W: Przybyszewski S. Synagoga szatana i inne eseje. Matuszek, G. (red.). Kraków: Oficyna Literacka, s. 158-225.

/// Przybyszewski, S. 2003a. Il regno doloroso. Kraków: Zielona Sowa.

/// Przybyszewski, S. 2003b. Requiem aeternam. W: Tenże. Poematy prozq. Matuszek, G. (red.). Kraków: Wydawnictwo Literackie, s. 43-95.

/// Ricoeur, P. 1986. Symbolika złła. Przeł. Cichowicz, S. i Ochab, M. Warszawa: Instytut Wydawniczy PAX.

/// Sheppard, R. 1998. Problematyka modernizmu europejskiego. Przeł. Wawrzyszko, P. W: Nycz, R. (red.). Odkrywanie modernizmu. Pržektady $i$ komentarze. Kraków: Universitas, s. 71-140. 


\section{/// Abstrakt}

Artykuł „Demony Przybyszewskiego, czyli o szatanie wczesnej nowoczesności” na przykładzie twórczości polsko-niemieckiego artysty, czułego barometru ówczesnych przemian cywilizacyjnych, pokazuje patologie i ideologie, w jakie wciela się szatan nowoczesności. Blasfemie i demonomanie wyrażają wewnętrzną psychomachię epoki, rozgrywająca się między sakralnością, będąca w stanie utraty, i nihilistycznymi prądami, podmywającymi jej fundamenty. Satanistyczno-gnostyckie fantazmaty oraz figurę szatana można traktować jako obronę przed nihilizmem i anarchizmem oraz metafizyczną pustką „świata bez Boga”. Autorka artykułu szatana nowoczesności dostrzega również w Ja, opanowanym przez demoniczne moce nieświadomości oraz demony pychy, lęku i obłędu, a także szaleństwa ciała i duszy (demony płci i sztuki). Twórczość Przybyszewskiego jawi się jako interesujący dokument katastroficznego „zbiorowego obłędu”, suponujący, że ludzkość skażona jest ontyczna i antropologiczna ,ppatologia”, a życie jest szaleństwem.

Słowa kluczowe: Przybyszewski, nowoczesność, szatan, satanizm, nihilizm.

\section{/// Abstract. Przybyszewski's Demons or the Satan of Early Modernity}

The article uses Przybyszewski's writing as a litmus paper for testing different incarnations of ,the Satan of modernity" - civilizational developments, pathologies and ideologies. Blasfemies and demonomanias express internal psychomachia of the era, torn between fading sacrality and nihilistic currents undermining its foundations. Partially Satanist, partially Gnostic phantasmata and the figure of satan can be treated as a defence against nihilism and anarchism, against the metaphysical void of the „world without God”. The author also traces „the Satan of modernity” in the individual consumed by demonic power of unconsciousness, hubris, fear and madness, as well as insanity of the body and soul (demons of gender and art). Works of Przybyszewski can be viewed as an interesting documentation of catastrophical „collective insanity”, suggesting, that the mankind is flawed with ontic and anthropological „pathology” and life itself is insanity.

Keywords: Przybyszewski, modernity, satan, satanism, nihilism. 